\title{
The utility of omega-3 fatty acids in epilepsy \\ More than just a farmed tilapia!
}

\author{
Vera C. Terra', Ricardo M. Arida², Guilherme M. Rabello³, \\ Esper A. Cavalheiro ${ }^{3}$, Fulvio A. Scorza ${ }^{3}$
}

\begin{abstract}
The epilepsies are one of the most common serious brain disorders and 20 to $30 \%$ of people developing epilepsy continue to have seizures and are refractory to treatment with the currently available therapies. Approximately one in a 1000 patients with chronic epilepsy will die suddenly, unexpectedly, and without explanation, even with post-mortem examination and this phenomenon is called sudden unexplained death in epilepsy (SUDEP). Understanding the mechanisms underlying SUDEP may lead to the identification of previously unrecognized risk factors that are more amenable to correction. We discuss here the possible implications of omega-3 fatty acids consumption on SUDEP prevention. Key words: epilepsy, sudden death, omega-3.
\end{abstract}

\section{A utilidade do ácido graxo ômega-3 na epilepsia: mais do que uma criação de tilápias!}

\section{RESUMO}

As epilepsias encontram-se entre as mais sérias doenças neurológicas; 20 a 30\% dos pacientes com epilepsia continuam apresentando crises e são refratários as terapias disponíveis atualmente. Aproximadamente um em cada 1000 pacientes com epilepsia crônica irá morrer de forma súbita, não esperada e sem explicação, mesmo com o exame pós-morte. Este fenômeno é denominado morte súbita e inesperada em epilepsia (SUDEP). Compreender os mecanismos envolvidos nos casos de SUDEP pode levar à identificação de fatores ainda não reconhecidos e passíveis de serem corrigidos. Discutiremos a seguir as possíveis implicações do consumo do ácido graxo ômega-3 na prevenção dos casos de SUDEP.

Palavras-chave: epilepsia, morte súbita, ômega-3.

The epilepsies are one of the most common serious brain disorders and it knows no age, racial, social class, geographic, or national boundaries ${ }^{1}$. Several studies have reported that approximately 50 million people worldwide have epilepsy and that between 70 and $80 \%$ of people developing epilepsy will go into remission, while the remaining patients continue to have seizures and are refractory to treatment with the currently available therapies $^{2,3}$. Furthermore, $80 \%$ of the 50 million people who have epilepsy live in countries with poor resources and this apparent discrepancy between rich and poor countries could be due by higher mortality in people with epilepsy in the developing world than in more affluent countries ${ }^{4,5}$. In this context, it has been described that each year about one in a 1000 patients with chronic epilepsy will die suddenly, unexpectedly, and without explanation, even with postmortem examination ${ }^{6}$. In the vernacular of the world of epilepsy, this phenomenon is called sudden unexplained death in epilepsy (SUDEP) ${ }^{6}$. Actually, epilepsy is as-

\section{Support \\ This work was supported by CNPq, FAPESP-CInAPCe, and FAEPA}

Received 11 August 2010

Received in final form 10 September 2010
'Centro de Cirurgia de Epilepsia (CIREP), Departamento de Neurociências e Ciências do Comportamento, Faculdade de Medicina de Ribeirão Preto, Universidade de São Paulo, Ribeirão Preto SP, Brazil; ${ }^{2}$ Departamento de Fisiologia, Universidade Federal de São Paulo/Escola Paulista de Medicina (UNIFESP/EPM), São Paulo SP, Brazil; ${ }^{3}$ Disciplina de Neurologia Experimental, Universidade Federal de São Paulo/Escola Paulista de Medicina (UNIFESP/EPM), São Paulo SP, Brazil. 
sociated with a two- to three-fold increase in mortality compared to the general population, and SUDEP is the most important direct epilepsy-related cause of death ${ }^{7}$. To date, a number of associated factors for SUDEP have been assessed in a number of studies but the results are not wholly consistent between them ${ }^{8,9}$. These include refractoriness of the epilepsy, presence of generalized tonic-clonic seizures, polytherapy with antiepileptic drugs, young age, duration of the seizure disorder ranging from 15 to 20 years, early onset of epilepsy and winter temperatures ${ }^{9,10}$. Additionally, knowledge of risk factors underlying SUDEP could guide investigations into its pathophysiologic mechanisms ${ }^{11}$. Conversely, understanding the mechanisms underlying SUDEP may lead to the identification of previously unrecognized risk factors that are more amenable to correction ${ }^{11}$. Although different mechanisms play a role in different cases, there are indications that cardiac arrhythmia during and between seizures play a potential pathomechanism for SUDEP ${ }^{9,12}$. Thus, considering that efforts to prevent and control seizures should be directed towards removing the causes of SUDEP ${ }^{13}$, several experimental and clinical studies have been clearly demonstrated that complementary medical therapies, especially omega- 3 fatty acids, are often tried by patients with epilepsy to control their seizures and hence SUDEP. In brief, the first randomized trial of omega-3 supplementation in patients with chronic epilepsy were encouraging, demonstrating a transient effect on seizure control that was not confirmed by other research group, but additional trials are required ${ }^{14,15}$. Although these results did not totally confirm that omega-3 fatty acids supplementation reduce the frequency of epileptic seizures in patients with refractory epilepsy; they established the safety of omega-3 supplementation in people with epilepsy ${ }^{15}$.

Polyunsaturated fatty acids (PUFAs) docosahexaenoic acid (DHA, 22: 6n-3) are major components of membrane phospholipids in brain tissue ${ }^{16}$. The eicosanoids play important roles in neural function including sleep induction, long term potentiation, spatial learning and synaptic plasticity, resolution of inflammation (lipoxins) and anti-inflammatory and neuroprotective bioactivity (dihydroxy-docosatriene, neuroprotectin D1, formed from DHA $)^{17}$. Diets deficient in omega 3 PUFA lead to reduced DHA in the brain and increased turnover of arachidonic acid to eicosanoids, an effect which is overcome by restoring the omega 3 PUFA to the diet ${ }^{17}$.

Studies in mice reported that both omega- 3 and omega- 6 fatty acids protect cells from oxidative stress and suppress apoptosis and PUFA supplementation may have neuroprotective effects ${ }^{18}$. Also, it has been demonstrated that n-3 PUFA treatment increased BDNF protein levels in the motor cortex of mice ${ }^{19}$, enhances hippocampal neurogenesis, with an increase in the number of prolifer- ating neurons and density of dendritic spines of CA1 pyramidal neurons in the hippocampus ${ }^{20}$.

Similarly, studies had demonstrated that DHA reduced expressions of tumor necrosis factor-alpha, interleukin-6, nitric oxide synthase, and cyclo-oxygenase-2, induced by interferon-gamma, and induced upregulation of heme oxygenase- 1 in microglia ${ }^{21}$.

Using the pilocarpine model of epilepsy, a valuable tool to study the pathogenesis of temporal lobe epilepsy in human condition, our research group was the first to demonstrate that chronic treatment with omega-3 promotes neuroprotection and positive plastic changes in the brain of rats with epilepsy ${ }^{22}$, with a decreased in neuronal death in CA1 and CA3 subfields of the hippocampus. This could be attributed to n-3 PUFAs ion channel modulation $^{23-25}$, and anti-inflammatory action.

In in vitro studies, DHA has been reported to inhibit epileptiform activity and synaptic transmission mainly through the frequency-dependent blockade of $\mathrm{Na}+$ channels in the rat hippocampus ${ }^{23}$, and to stabilize neuronal membrane by suppressing voltage-gated $\mathrm{Ca} 2+$ currents $^{26}$ and $\mathrm{Na}+$ channels $^{24}$.

After these research evidences of beneficial effects of omega- 3 fatty acids in the brain and clinical reports of transitory seizure control patients with epilepsy should be encourage to eat fish more frequently. The association between fish consumption and low rates risk of cardiovascular disease has been studied nearly four decades ago with the consumption of seafood diets by Greenland Eskimos, Alaskan Natives and Japanese people residing in fishing villages ${ }^{27-30}$. Recently, several noncardiovascular actions of fish consumption have also been described, suggesting that a regular diet of fish could be of benefit in many conditions ${ }^{31}$, including various central nervous system (CNS) diseases ${ }^{32,33}$. Concerning CNS, we need to keep in mind that omega-3 fatty acids (from fatty fish in the human diet) also appear effective on the structure, the biochemistry, the physiology and thus the function of the brain $^{34,35}$. As we know, the brain is one of the organs with the highest level of lipids (fats). Brain lipids, formed of fatty acids, participate in the structure of membranes, for instance $50 \%$ fatty acids are polyunsaturated in the gray matter, $1 / 3$ are of the omega- 3 family, and are thus of dietary origin $^{36}$. Thus, seafood (commonly found in fish and fish oil) is the only foods that provide large amounts of omega- $3^{31,32,36}$. Fish can be classified into lean fish that store lipid in the liver (eg, cod) or "fatty" ("oily") fish that store lipid in the flesh (eg, salmon, tuna, sardines and herring) ${ }^{31}$. On the other hand, it is very important to emphasise that some types of fish may contain high levels of methylmercury, PCBs (polychlorinated biphenyls), dioxins and other environmental contaminants ${ }^{32,37-39}$. Levels of these substances are generally highest in older, larger and predato- 
ry fish ${ }^{32,37-39}$. So, as the concentration of methylmercury is increased in predatory fish, the best seafood choices are those with nonpredatory characteristics. Anchovies, Atlantic herring, salmon, sardines, and trout have low levels of methylmercury, whereas tuna, shark, tilefish, and swordfish have high levels of methylmercury ${ }^{32,37-39}$. A study developed by researchers from Wake Forest University School of Medicine characterized the content of favorable and unfavorable polyunsaturated fatty acids (omega-3 and omega-6) found in commonly eaten fish, with closer inspection on the four most commonly consumed farmed fish (salmon, trout, tilapia and catfish) ${ }^{40}$. Tilapia is now the second (to farmed Atlantic salmon) most widely farmed fish in the world ${ }^{40}$. Based in all these facts, what we, as neuroscientists, should be thinking about it?

Firstly and most important, the health benefits of the omega- 3 in fish have been well documented ${ }^{40,41}$. Concerning CNS and associated disorders, the belief that "fish is brain food" has been held around the world for well over two thousand years ${ }^{33,42,43}$. Actually, it is clear that fish supplies omega-3 oils, essential for brain and eye tissue development in infants; it remains fundamental to those tissues throughout life $\mathrm{e}^{33,42}$. Furthermore, the implications of omega-3 deficiency on the brain are profound and span the entire human life cycle. Beginning in pregnancy, premature birth and its potential neurologic complications may result from omega-3 deficiency ${ }^{33,42}$. On the other hand, one observation deserves explanation here. After much discussion, consensus was reached on the importance around the balance of omega- 6 and omega- 3 fatty acids for homeostasis and normal development ${ }^{44}$. Thus, the ratio of omega- 6 to omega- 3 is an important determinant of health ${ }^{44}$. Anthropological evidence suggests that human ancestors evolved on a diet in which the ratio of omega-6/omega- 3 was about 1 , whereas in the Western diets, the ratio is $15 / 1$ to $17 / 1^{44}$. In these lines, it has been extensively demonstrated that excessive amounts of omega- 6 and a very high omega-6/omega-3 ratio, as is found in today's Western diets, is associated with serious physiological dysfunctions and contributes to the development of several diseases such as heart attacks, thrombotic stroke, arrhythmia, arthritis, osteoporosis, inflammation, mood disorders, obesity, and cancer ${ }^{44,45}$. In this context, these excessive amounts of omega- 6 fatty acids upsetting the balance that was characteristic during evolution when our genes were programmed to respond to diet and other aspects of the environment ${ }^{44}$. This consideration was recently demonstrated in an elegant study conducted by Weaver and colleagues that developed a dietary intervention strategy in which 27 healthy humans were fed a controlled diet mimicking the omega-6/omega- 3 ratios of early humans over 5 weeks ${ }^{46}$. For that, the authors then looked at the gene levels of immune sig- nals and cytokines that impact autoimmunity and allergy in blood cells. Thus, they found that many key signaling genes that promote inflammation were markedly reduced compared to a normal diet, including a signaling gene for PI3K protein, a critical early step in autoimmune and allergic inflammation responses. With these results, the authors demonstrated, for the first time in humans, that polyunsaturated fatty acids may exert their clinical effects via their capacity to regulate the expression of signal transduction genes and genes for proinflammatory cytokines $^{46}$. In sum, the importance of omega-3 essential fatty acids in the diet is now evident ${ }^{47}$. In order to improve the ratio of omega-6/omega-3, it will be necessary to decrease the intake of omega- 6 fatty acids from vegetable oils and meat and to increase the intake of omega- 3 fatty acids by increasing the intake of fish to two to three times per week ${ }^{47}$. Finally, the American Heart Association released a scientific statement, "Fish Consumption, Fish Oil, Omega-3 Fatty Acids, and Cardiovascular Disease" on the effects of omega-3 fatty acids on heart function (including antiarrhythmic effects), hemodynamics (cardiac mechanics) and arterial endothelial function ${ }^{48}$.

On the whole, there are a great number of evidences that omega- 3 fatty acids are very important for the normal functioning of the heart and the brain, while PUFA themselves are important in membrane structure and function ${ }^{17}$. The inhibitory effect of DHA on nitric oxide production and inflammatory process establishment may have a main role in omega-3 fatty acids mechanisms of action ${ }^{21}$. Our research group are totally in agreement with Professor Russo that concluded in his elegant study that it is really necessary to intensify the scientific efforts in order to clarify many controversial aspects of fish consumption in order to make human diet healthier ${ }^{49}$.

\section{REFERENCES}

1. de Boer HM, Mula M, Sander JW. The global burden and stigma of epilepsy. Epilepsy Behav 2008;12:540-546.

2. Sander JW. The epidemiology of epilepsy revisited. Curr Opin Neurol 2003; 16:165-170.

3. Kwan P, Sander JW. The natural history of epilepsy: an epidemiological view. J Neurol Neurosurg Psychiatry 2004;75:1376-1381.

4. Tomson T. Excess mortality in epilepsy in developing countries. Lancet Neurol 2006;5:804-805.

5. Scott RA, Lhatoo SD, Sander JW. The treatment of epilepsy in developing countries: where do we go from here? Bull World Health Organ 2001;79: 344-351.

6. Hirsch LJ, Hauser WA. Can sudden unexplained death in epilepsy be prevented? Lancet 2004;364:2157-2158.

7. Duncan JS, Sander JW, Sisodiya SM, Walker MC. Adult epilepsy. Lancet 2006; 367:1087-1100.

8. Surges R, Thijs RD, Tan HL, Sander JW. Medscape. Sudden unexpected death in epilepsy: risk factors and potential pathomechanisms. Nat Rev Neurol 2009;5:492-504.

9. Stollberger C, Finsterer J. Cardiorespiratory findings in sudden unexplained/ unexpected death in epilepsy (SUDEP). Epilepsy Res 2004;59:51-60.

10. Scorza FA, de Albuquerque M, Arida RM, Cavalheiro EA. Sudden unexpected death in epilepsy: are winter temperatures a new potential risk factor? Epilepsy Behav 2007;10:509-510. 
11. So EL. What is known about the mechanisms underlying SUDEP? Epilepsia 2008:49:93-98

12. Scorza FA, Colugnati DB, Pansani AP, Sonoda EY, Arida RM, Cavalheiro EA. Preventing tomorrow's sudden cardiac death in epilepsy today: what should physicians know about this? Clinics 2008;63:389-394.

13. Tomson T, Nashef L, Ryvlin P. Sudden unexpected death in epilepsy: current knowledge and future directions. Lancet Neurol 2008;7:1021-1031.

14. Yuen AW, Sander JW, Fluegel D, et al. Omega-3 fatty acid supplementation in patients with chronic epilepsy: a randomized trial. Epilepsy Behav 2005;7:253-258.

15. DeGiorgio CM, Miller P. N-3 fatty acids (eicosapentanoic and docosahexanoic acids) in epilepsy and for the prevention of sudden unexpected death in epilepsy. Epilepsy Behav 2008;13:712-713.

16. Green P, Hermesh H, Monselise A, Marom S, Presburger G, Weizman A. Red cell membrane omega-3 fatty acids are decreased in nondepressed patients with social anxiety disorder. Eur Neuropsychopharmacol 2006:16:107-113.

17. Tassoni D, Kaur G, Weisinger RS, Sinclair AJ. The role of eicosanoids in the brain. Asia Pac J Clin Nutr. 2008;17(Suppl 1):S220-S228.

18. Kim SJ, Zhang Z, Saha A, Sarkar C, Zhao Z, Xu Y, Mukherjee AB. Omega-3 and omega- 6 fatty acids suppress ER- and oxidative stress in cultured neurons and neuronal progenitor cells from mice lacking PPT1. Neurosci Lett 2010;2:292-296.

19. Bousquet M, Gibrat C, Saint-Pierre M, Julien C, Calon F, Cicchetti F. Modulation of brain-derived neurotrophic factor as a potential neuroprotective mechanism of action of omega-3 fatty acids in a parkinsonian animal model. Prog Neuropsychopharmacol Biol Psychiatry 2009;13:1401-1408.

20. He C, Qu X, Cui L, Wang J, Kang JX. Improved spatial learning performance of fat- 1 mice is associated with enhanced neurogenesis and neuritogenesis by docosahexaenoic acid. Proc Natl Acad Sci U S A. 2009;7:11370-11375.

21. Lu DY, Tsao YY, Leung YM, Su KP. Docosahexaenoic acid suppresses neuroinflammatory responses and induces heme oxygenase-1 expression in BV-2 microglia: implications of antidepressant effects for omega-3 fatty acids. Neuropsychopharmacology 2010, in press

22. Ferrari D, Cysneiros RM, Scorza CA, et al. Neuroprotective activity of omega-3 fatty acids against epilepsy-induced hippocampal damage: quantification with immunohistochemical for calcium-binding proteins. Epilepsy Behav 2008;13:36-42

23. Young C, Gean P, Chiou LC, Shen Y. Docosahexaenoic acid inhibits synaptic transmission and epileptiform activity in the rat hippocampus. Synapse 2000;37:90-94.

24. Xiao YF, Kang JX, Morgan JP, Leaf A. Blocking effects of polyunsaturated fatty acids on $\mathrm{Na}+$ channels of neonatal rat ventricular myocytes. Proc Natl Acad Sci USA 1995;92:11000-11004.

25. Xiao Y, Li X. Polyunsatured fatty acids modify mouse hippocampal neuronal excitability during excitotoxic or convulsant stimulation. Brain Res 1999:846:112-121.

26. Xiao YF, Gomez AM, Morgan JP, Lederer WJ, Leaf A. Suppression of voltage-gated L-type Ca2+ currents by polyunsaturated fatty acids in adult and neonatal rat ventricular myocytes. Proc Natl Acad Sci USA 1997;94: 4182-4187.

27. He K. Fish, long-chain omega-3 polyunsaturated fatty acids and prevention of cardiovascular disease: eat fish or take fish oil supplement? Prog Cardiovasc Dis 2009:52:95-114.
28. Middaugh JP. Cardiovascular deaths among Alaskan Natives,1980-86. Am J Public Health 1990:80:282-285.

29. Kagawa Y, Nishizawa M, Suzuki M, et al. Eicosapolyenoic acids of serum lipids of Japanese islanders with low incidence of cardiovascular diseases. J Nutr Sci Vitaminol 1982;28:441-453.

30. Bang HO, Dyerberg J, Hjøorne N. The composition of food consumed by Greenland Eskimos. Acta Med Scand 1976;200:69-73.

31. Calder PC, Yaqoob P. Understanding omega-3 polyunsaturated fatty acids. Postgrad Med 2009;121:148-157.

32. Scorza FA, Cysneiros RM, Terra VC, et al. Omega-3 consumption and sudden cardiac death in schizophrenia. Prostaglandins Leukot Essent Fatty Acids 2009;81:241-245

33. Mazza M, Pomponi M, Janiri L, Bria P, Mazza S. Omega-3 fatty acids and antioxidants in neurological and psychiatric diseases: an overview. Prog Neuropsychopharmacol Biol Psychiatry 2007;31:12-26.

34. Bourre JM. Dietary omega-3 fatty acids and psychiatry: mood, behaviour, stress, depression, dementia and aging. J Nutr Health Aging 2005;9:31-38.

35. Bourre JM. Effects of nutrients (in food) on the structure and function of the nervous system: update on dietary requirements for brain. Part 2: macronutrients. J Nutr Health Aging 2006;10:386-399.

36. Bourre JM. Omega-3 fatty acids in psychiatry. Med Sci 2005;21:216-221.

37. Smith KM, Sahyoun NR. Fish consumption: recommendations versus advisories, can they be reconciled? Nutr Rev 2005;63:39-46.

38. Jeejeebhoy KN. Benefits and risks of a fish diet: should we be eating more or less? Nat Clin Pract Gastroenterol Hepatol 2008;5:178-179.

39. Fish: friend or foe? In addition to heart-healthy omega-3 fats, seafood can carry mercury and other toxins. For most people, the benefits of eating fish far outweigh the risks. Harv Heart Lett 2007:17:4-6.

40. Weaver KL, Ivester P, Chilton JA, Wilson MD, Pandey P, Chilton FH. The content of favorable and unfavorable polyunsaturated fatty acids found in commonly eaten fish. J Am Diet Assoc 2008;108:1178-1185.

41. Mozaffarian D, Psaty BM, Rimm EB, et al. Fish intake and risk of incident atrial fibrillation. Circulation 2004;110:368-373.

42. Innis SM. Omega-3 Fatty acids and neural development to 2 years of age: do we know enough for dietary recommendations? J Pediatr Gastroenterol Nutr 2009;48 (Suppl):S16-S24

43. Scorza FA, Cysneiros RM, Terra VC, Arida RM, Scorza CA, Cavalheiro EA. From Galapagos to the labs: Darwinian medicine and epilepsy today. Epilepsy Behav 2009;16:388-390.

44. Simopoulos AP. The importance of the ratio of omega-6/omega-3 essential fatty acids. Biomed Pharmacother 2002;56:365-379.

45. Calder PC. N-3 polyunsaturated fatty acids, inflammation, and inflammatory diseases. Am J Clin Nutr 2006;83:1505-1519.

46. Weaver KL, Ivester P, Seeds M, Case LD, Arm JP, Chilton FH. Effect of dietary fatty acids on inflammatory gene expression in healthy humans. J Biol Chem 2009;284:15400-15407.

47. Simopoulos AP. Omega-3 fatty acids in inflammation and autoimmune diseases. J Am Coll Nutr 2002;21:495-505.

48. Kris-Etherton PM, Harris WS, Appel LJ. American Heart Association. Nutrition Committee. Fish consumption, fish oil, omega-3 fatty acids, and cardiovascular disease Circulation 2002:106:2747-2757.

49. Russo GL. Dietary n-6 and n-3 polyunsaturated fatty acids: from biochemistry to clinical implications in cardiovascular prevention. Biochem Pharmacol 2009:77:937-946. 